Article

\title{
The Impact of Dietary Berberine Supplementation during the Transition Period on Blood Parameters, Antioxidant Indicators and Fatty Acids Profile in Colostrum and Milk of Dairy Goats
}

\author{
Navid Ghavipanje ${ }^{1, * \mathbb{D}}$, Mohammad Hasan Fathi Nasri ${ }^{1}$, Seyyed Homayoun Farhangfar ${ }^{1}$, Seyyed Ehsan Ghiasi ${ }^{1}$ \\ and Einar Vargas-Bello-Pérez ${ }^{2, * \mathbb{D}}$ \\ 1 Department of Animal Science, Faculty of Agriculture, University of Birjand, Birjand 97175-331, Iran \\ hfathi@birjand.ac.ir (M.H.F.N.); hfarhangfar@birjand.ac.ir (S.H.F.); s.e.ghiasi@birjand.ac.ir (S.E.G.) \\ 2 Department of Veterinary and Animal Sciences, Faculty of Health and Medical Sciences, \\ University of Copenhagen, DK-1870 Frederiksberg C, Denmark \\ * Correspondence: navid.ghavipanje@birjand.ac.ir (N.G.); evargasb@sund.ku.dk (E.V.-B.-P.)
}

Citation: Ghavipanje, N.; Fathi Nasri, M.H.; Farhangfar, S.H.; Ghiasi, S.E.; Vargas-Bello-Pérez, E. The Impact of Dietary Berberine Supplementation during the Transition Period on Blood Parameters, Antioxidant Indicators and Fatty Acids Profile in Colostrum and Milk of Dairy Goats. Vet. Sci. 2022, 9, 76. https://doi.org/ 10.3390 /vetsci9020076

Academic Editor:

Giuseppe Campanile

Received: 7 January 2022

Accepted: 9 February 2022

Published: 11 February 2022

Publisher's Note: MDPI stays neutral with regard to jurisdictional claims in published maps and institutional affiliations.

Copyright: (C) 2022 by the authors. Licensee MDPI, Basel, Switzerland. This article is an open access article distributed under the terms and conditions of the Creative Commons Attribution (CC BY) license (https:// creativecommons.org/licenses/by/ $4.0 /)$.

\begin{abstract}
The objective of this study was to investigate the effect of berberine (BBR) supplementation on productivity, antioxidant markers, and the fatty acid (FA) profile in the colostrum and milk of goats. Twenty-four primiparous Saanen goats were supplemented with $0,1,2$, and $4 \mathrm{~g} / \mathrm{d}$ (per goat) of BBR in control (CON), BBR1, BBR2, and BBR4 groups ( $n=6$ per group), respectively, from 21 days before expected kidding to 21 days after parturition. Blood sampling was carried out at $-21,-14,-7$, $0,7,14$, and $21 \mathrm{~d}$ relative to delivery. Colostrum was collected within the first and second milking ( $\mathrm{d} 1$ of lactation), and milk was harvested weekly after kidding. Both BBR2 and BBR4 increased dry matter intake (DMI) $(p \leq 0.05)$ and energy balance (EB) as well as colostrum and milk production. Both BBR2 and BBR4 decreased $(p \leq 0.05)$ plasma levels of cholesterol, haptoglobin, and ceruloplasmin, while elevating the plasma albumin and paraoxonase $(p \leq 0.05)$, which may indicate that BBR mitigates inflammation during the transition period. BBR reduced $(p \leq 0.05)$ malondialdehyde (MDA) and increased ( $p \leq 0.05$ ) total antioxidant capacity (TAC), superoxide dismutase (SOD), glutathione peroxidase (GSH-Px), and catalase (CAT) in blood, colostrum, and milk. Concentrations of de novo fatty acid in colostrum and milk were increased $(p \leq 0.05)$ with both BBR2 and BBR4. Free fatty acid (FFA) concentration in colostrum and milk fat were lower $(p \leq 0.05)$ in BBR2 and BBR4 compared to CON. The concentration of saturated fatty acids (SFAs) in colostrum and milk fat increased $(p \leq 0.05)$ with BBR2 and BBR4, while unsaturated fatty acids (USFAs) decreased $(p \leq 0.05)$ in milk. In summary, supplementation with at least $2 \mathrm{~g} / \mathrm{d}$ BBR may enhance the EB and antioxidant status of dairy goats.
\end{abstract}

Keywords: antioxidants; berberine; fatty acid profile; inflammation; transition goat

\section{Introduction}

The perinatal dairy goat, from approximately $21 \mathrm{~d}$ prepartum to $21 \mathrm{~d}$ postpartum, is commonly defined as the transition goat $[1,2]$. Transition goats are metabolically challenged during that period [2,3]. Apart from negative energy balance (NEB) caused by high energy requirements at the beginning of lactation and an inadequate feed intake [2,3], goats during the transition period can also show elevated plasma free fatty acid concentration [2], low-grade inflammation [2,3], and oxidative stress [1], similar to cows [4-7].

Moreover, throughout the transition period, dairy goats can have significant alterations of metabolic status, pro-oxidant/antioxidant status, and in their immune systems $[1,8]$. This oxidative stress is caused by, among other things, enhanced metabolic activity in consequence of the increased energy demands, reduced antioxidant capacity, and increased reactive oxygen species (ROS) production $[8,9]$.

Research has shown that NEB, along with increased circulated non-esterified fatty acids (NEFA) and $\beta$-hydroxybutyrate (BHBA), induces immunosuppression and increases 
the release of positive acute phase proteins, such as haptoglobin and ceruloplasmin in transition cows $[4,10]$; however, limited information is available for dairy goats during the transition period [1]. Also, alterations in a dairy animal's metabolic homeostasis might change the milk component and FA profile [11]. It is well established [12,13] in dairy cows that not only milk fat content can be affected but also single milk FA, which can also be used as indicators of an animal's metabolic status. Studies have verified that the milk composition and FA profile are influenced by the lactation stage [14] and energy status [15] in dairy goats; however, there is still little known about indicators in milk for assessing the metabolic status of early-lactation goats.

Berberine (5,6-dihydrodibenzo [a,g] quinolizinium), a natural isoquinoline alkaloid from the protoberberine class, is originated from different herbal families such as the Berberidacae, Ranunculaceae, and Papaveraceae families [16]. The main sources of BBR are the rhizomes, roots, and stem bark of barberry (Berberis vulgaris), goldenseal (Hydrastis canadensis), coptis (Coptis chinensis), tree turmeric (Berberis aristata), and Oregon grape (Berberis aquifolium) $[17,18]$. During the last few decades, many studies have shown that BBR exerts various beneficial effects [16-19], such as lowering blood glucose, regulating blood lipids, encouraging antioxidant activity, reducing inflammation, and increasing insulin sensitivity, thus ameliorating insulin resistance (IR) [16-19]. In addition, the therapeutic benefits of BBR in treating type 2 diabetes mellitus and metabolic syndromes have been reviewed previously [16-20]. BBR inhibits oxidative stress and inflammation in a variety of tissues, including liver, adipose, kidney, and pancreas [19].

To the best of our knowledge, scarce information is available with regard to NEB, oxidative stress, and inflammation in transition goats as well as on health status and milk production. This article is part of a larger study that evaluated the effects of BBR supplementing on performance, glucose metabolism, insulin sensitivity, inflammation, and oxidative stress status in periparturient dairy goats. Our companion paper [21] revealed that BBR ameliorates the NEB in transition goats. The objective of the preset study was to reassess BBR supplementation as a novel preventive approach towards boosting antioxidant indicators in blood and milk, as well as its effects on FA profile in the colostrum and milk of goats during the transition period.

\section{Materials and Methods}

This study was carried out on an experimental farm at the University of Birjand, located in Birjand, Iran (longitude and latitude, $37.42^{\circ} \mathrm{N}$ and $57.31^{\circ} \mathrm{E}$ ). The research protocol and animal care were in accordance with guidelines of the Iranian Council of Animal Care [22] on the protection of animals used for scientific purposes.

\subsection{Design, Animal, and Diet}

The trial was carried out with 24 Saanen dairy goats during the last 21 days of pregnancy and the first 21 days of lactation. Goats were housed in individual stalls $(1.8 \mathrm{~m} \times 1.6 \mathrm{~m})$. Pre- and post-partum diets were formulated to be isocaloric [2.60 and 2.90 Mcal metabolizable energy (ME) dry matter (DM) basis in pre- and post-partum diets, respectively] and isonitrogenous [18.5 and $15.5 \%$ crude protein $(\mathrm{CP}) \mathrm{DM}$ basis in preand post-partum diets, respectively] in order to fulfill the requirements of the national research council (NRC) [23] (Table 1). Goats were fed a total mixed ration (TMR) with a 45:55 forage/concentrate ratio, twice daily in equal amounts (06:00 and 14:00 h) for ad libitum consumption and had free access to water. 
Table 1. Ingredients, chemical analysis and nutritive value dry matter (DM) basis of the pre- and post-partum basal total mixed rations.

\begin{tabular}{|c|c|c|}
\hline & \multicolumn{2}{|c|}{ Diets $^{a}$} \\
\hline & Pre-Partum & Post-Partum \\
\hline \multicolumn{3}{|l|}{ Ingredient (\% of DM) } \\
\hline Alfalfa hay & 4.00 & 29.5 \\
\hline Corn silage & 34.3 & 10.8 \\
\hline Wheat straw & 17.9 & 5.00 \\
\hline Barley grain, ground & 7.70 & 10.8 \\
\hline Corn grain, ground & 31.5 & 22.2 \\
\hline Soybean meal & 1.00 & 17.0 \\
\hline Wheat bran & 1.80 & 2.20 \\
\hline Calcium-carbonate & 0.90 & 1.00 \\
\hline Minerals and vitamins premix ${ }^{b}$ & 0.90 & 0.50 \\
\hline Salt & 0.00 & 1.00 \\
\hline \multicolumn{3}{|l|}{ Chemical composition } \\
\hline Metabolizable energy, Mcal/kg of DM & 2.60 & 2.90 \\
\hline Crude protein $(\% \mathrm{DM})$ & 18.5 & 15.5 \\
\hline Ether extract (\% DM) & 2.50 & 2.50 \\
\hline Ash $(\% \mathrm{DM})$ & 7.60 & 8.00 \\
\hline Natural detergent fiber (\% DM) & 43.0 & 37.3 \\
\hline Non-fibrous carbohydrates $(\% \mathrm{DM})^{\mathrm{c}}$ & 38.0 & 36.7 \\
\hline \multicolumn{3}{|c|}{ 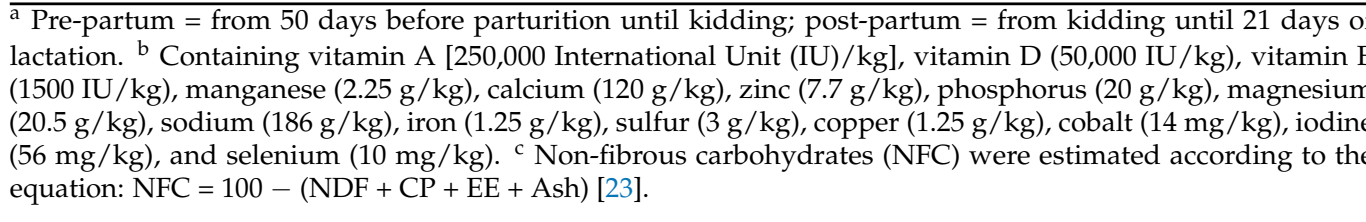 } \\
\hline
\end{tabular}

Amounts of feed offered and refused were recorded daily. Following parturition and through $21 \mathrm{~d}$ of lactation, milking was performed daily using a portable milking machine (Tim Gibson Ltd., Bedale, UK) at 05:30 and 15:30 h. Goats were grouped in a completely randomized design, and treatments were supplementation of $0,1,2$, and $4 \mathrm{~g} / \mathrm{d}$ of BBR for each goat in control (CON), BBR1, BBR2, and BBR4 groups ( $n=6$ per group), respectively. These dosages corresponded to 0 to $100 \mathrm{mg}$ dietary BBR per $\mathrm{kg}$ body weight (BW). Berberine hydrochloride (BBR HCL) (BulkSupplements, Eastgate, Henderson, NV, USA) was put in gelatin capsules (Irancapsul, Tehran, Iran) and orally administrated to each goat with a balling gun (Pars Khavar, Tehran, Iran) before morning feeding from 21 days prior to anticipated kidding date through 21 days of lactation. To the best of our knowledge, there is no comparable data regarding the effects of BBR in cattle; however, the levels of BBR were chosen based on previous in vitro [18] and in vivo [16-20] experiments.

\subsection{Blood Collection and Analysis}

Blood (10 mL/goat) was collected from each animal after overnight fasting, once weekly from 21 days before expected kidding, up to 21 days of lactation. Blood was harvested from the jugular vein using heparinized blood collection tubes (RotexMedica, Trittau, Germany). Blood samples were centrifuged at $3000 \times g$ at room temperature for $15 \mathrm{~min}$. Plasma was obtained and stored at $-80^{\circ} \mathrm{C}$ until analyzed. Plasma samples were analyzed for concentrations of albumin, cholesterol, glucose, and bilirubin using commercial kits (Pars Azmun Co., Ltd., Tehran, Iran) by an autoanalyzer (BT 1500, Biotecnica SpA, Rome, Italy). Plasma haptoglobin and ceruloplasmin were determined using commercial test kits (Randox Laboratories Ltd., Ardmore, UK). Plasma paraoxonase (PON) activity was measured by adapting the method of Ferre' et al. [24]. Serum insulin level was measured using enzyme linked immunosorbent assay kit (Monobind Inc., Lake Forest, CA, USA). In addition, BHBA and NEFA were measured using commercial kits (Randox Laboratories Ltd., Ardmore, UK). 


\subsection{Colostrum and Milk Collection and Analysis}

Colostrum yield per individual goat was determined as the sum of the amounts obtained from the first and second milkings (day 1 after kidding), and colostrum samples ( $50 \mathrm{~mL} /$ goat) were taken. Goats were milked twice daily at 05:30 and 15:30 h, and milk yield was recorded after each milking. Weekly milk samples were collected from 2 consecutive milking times following parturition. Colostrum and milk samples were preserved with potassium bichromate and stored at $4{ }^{\circ} \mathrm{C}$ until analyzed. Samples for milk fatty acid (FA) and antioxidant concentrations did not have chemical preservation. Milk fat, true protein, lactose, total solids, and solid non-fat content were determined using a Fourier transform mid-infrared (FTIR) spectrophotometer (Lactoscope FTA, Delta Instruments, Drachten, the Netherlands) at the Rojan Alvand certified laboratory (Karaj, Iran). The prediction models used were the optimized basic model of filtered wavelengths and intercorrection factors described by Kaylegian et al. [25]. The reference methods for fat, protein, and lactose measurement were determined in duplicate using the following validated methods [26]: fat by modified Mojonnier ether extraction (method 989.05), true protein by Kjeldahl analysis (method 991.22), and lactose by enzymatic analysis (method 2006.06).

De novo and preformed milk FA were estimated by FTIR using the partial least squares (PLS) prediction models described by Woolpert et al. [27]. Gas-liquid chromatography reference chemistry for calibration of milk FA parameters was used, as described by Wojciechowski and Barbano [28].

\subsection{Antioxidants Assays in Blood Plasma, Colostrum and Milk}

The level of malondialdehyde (MDA) in plasma, colostrum, and milk was determined using the thiobarbituric acid method according to Placer et al. [29]. The results were obtained as $\mathrm{nmol} / \mathrm{mL}$ using the colorimetric method. Total antioxidant capacity (TAC) in the colostrum and milk was determined by the ferric-reducing antioxidant power (FRAP) method [30] with some modifications according to Smet et al. [31]. Before measuring absorbance, a centrifugation step was introduced (1300 $\mathrm{g}$ for $5 \mathrm{~min})$, resulting in a clear medium. Plasma TAC was measured using a Randox kit (Crumlin, County Antrim, UK) in which 2.2-azino-bis (3-ethylbenzothiazoline-6-sulfanate, ABTS) was incubated with a peroxidase and $\mathrm{H}_{2} \mathrm{O}_{2}$ to produce the radical cation $\mathrm{ABTS}^{+}$. This had a stable blue-green color, which is measured at $600 \mathrm{~nm}$. The enzymatic activities of superoxide dismutase (SOD), glutathione peroxidase (GSH-Px), and catalase (CAT) in either blood or colostrum/milk were measured using the commercial Randox kit (Randox Laboratories Ltd., Ardmore, UK) according to the manufacturers' procedures.

\subsection{BCS, Energy Calculation, and Other Measurements}

For all goats, body condition score (BCS) was determined on days $-21,-14,-7,0,7$, 14 , and 21, relative to parturition. The same technician assessed BCS for each doe on a scale of 1 (emaciated) to 5 (over-conditioned) as described by Villaquiran et al. [32].

Pre- and post-partum energy balance (EB) was calculated according to NRC [23]:

$$
\begin{gathered}
\mathrm{EB}=\mathrm{NEC}-\mathrm{NEM}-\mathrm{NEG}-\mathrm{NEP} \\
\mathrm{NEC}=\mathrm{NEL} / \mathrm{kg} \text { of } \mathrm{DM} \times \mathrm{DMI} \\
\mathrm{NEM}=\mathrm{BW} 0.75 \times 0.08 \times 1.1
\end{gathered}
$$

$$
\mathrm{NEG}=(0.00318 \times \text { days of gestation }-0.0352) \times(\text { kid birth weight } / 0.45) / 0.218
$$

$\mathrm{NEP}=$ milk, $\mathrm{kg} \times[(0.0929 \times$ fat,$\%)+(0.0547 \times$ protein,$\%)+(0.0395 \times$ lactose,$\%)]$

where, NEC = net energy consumed, NEL = net energy of lactation, NEM = net energy of maintenance, NEG = net energy requirement of pregnancy, and NEP = net energy output 
in milk. In addition, metabolizable protein intake (MPI) was obtained from the following formula [23]:

$$
\operatorname{MPI}(\mathrm{g} / \mathrm{d})=\mathrm{DMI}(\mathrm{kg}) \times \mathrm{MP}(\mathrm{g} / \mathrm{kg} \mathrm{DMI})
$$

\subsection{Data Analysis}

Collected data were analyzed in a completely randomized design using the MIXED procedure of Statistical Analysis System 9.2 software [33]. The fixed effects in the model were: the dietary treatment (BBR supplementation), the time of sampling (Time), and their interaction (Diet $\times$ Time), while individual goats were included as a random factor. Three covariance structures were tested (autoregressive-1, spatial power, and unstructured), and the one resulting in the lowest Akaike information criterion was chosen. The REPEATED procedure was used for all variables. Least square means (LSM) separation between time points was performed using the PDIFF statement by Tukey's test and presented as $\mathrm{LSM} \pm \mathrm{SEM}$. Significance was declared at $p \leq 0.05$ and trends at $p \leq 0.10$ and $p \geq 0.05$.

\section{Results}

\subsection{DMI, BCS, and EB}

Supplementation of either BBR2 or BBR4 increased ( $p \leq 0.05)$ the DMI of goats in the overall transition period as compared to the control group (Table 2). Moreover, intakes of NEL and MP were higher $(p \leq 0.05)$ for goats receiving supplemental BBR2 or BBR4. The energy balance values as Mcal/d or \% requirements of goats were increased $(p \leq 0.05)$ by BBR supplementation, followed by BBR2 and BBR4. Goats supplemented with BBR tended $(p=0.10)$ to lose less BCS than unsupplemented goats. However, BW ( $p \geq 0.05)$ was similar between treatments.

Table 2. Effect of Berberine (BBR) supplementation on intakes of dry matter (DMI), net energy for lactation (NEL), and metabolizable protein (MP) and body condition score (BCS) of transition dairy Saanen goats ${ }^{1}$.

\begin{tabular}{|c|c|c|c|c|c|c|}
\hline \multirow{2}{*}{ Item $^{2}$} & \multicolumn{4}{|c|}{ Treat $^{3}$} & \multirow{2}{*}{ SEM $^{5}$} & \multirow{2}{*}{$p$ Values } \\
\hline & $\mathrm{CON}$ & BBR1 & BBR2 & BBR4 & & \\
\hline DMI, Kg/d & $1.58^{\mathrm{b}}$ & $1.68^{b}$ & $1.97^{\mathrm{a}}$ & $1.94^{\mathrm{a}}$ & 0.040 & $<0.001$ \\
\hline NEL intake, Mcal/d & $1.99^{b}$ & $2.13^{b}$ & $2.50^{\mathrm{a}}$ & $2.45^{\mathrm{a}}$ & 0.054 & $<0.001$ \\
\hline MP intake, g/d & $208.37^{b}$ & $224.77^{b}$ & $264.09^{a}$ & $258.47^{a}$ & 6.152 & $<0.001$ \\
\hline $\begin{array}{c}\text { Energy balance, } \\
\text { Mcal/d }\end{array}$ & $0.58^{c}$ & $0.73 \mathrm{bc}$ & $1.25^{\mathrm{a}}$ & $1.22^{\mathrm{ab}}$ & 0.121 & 0.004 \\
\hline Energy balance, \% & $123.46^{b}$ & $138.27^{b}$ & $182.63^{a}$ & $183.72^{\mathrm{a}}$ & 6.670 & $<0.001$ \\
\hline Body weight, $\mathrm{Kg}$ & 46.12 & 46.92 & 47.26 & 46.51 & 1.511 & 0.854 \\
\hline $\mathrm{BCS}^{4}$, point & 3.31 & 3.34 & 3.48 & 3.47 & 0.0570 & 0.102 \\
\hline
\end{tabular}

${ }^{\mathrm{a}-\mathrm{c}}$ Within a row, means without a common uppercase superscript letter differ $(p<0.05) .{ }^{1}$ Values are least-square means. ${ }^{2}$ Data cover the last 21 days of gestation through the first 21 days of lactation. ${ }^{3} \mathrm{CON}=$ diet without BBR supplementation; BBR1, BBR2, BBR4 = diet supplemented with 1, 2, and $4 \mathrm{~g} / \mathrm{d}$ of BBR, respectively. ${ }^{4}$ Body condition score (BCS). ${ }^{5} \mathrm{SEM}=$ pooled standard error of mean.

\subsection{Biomarkers of Inflammation and Health Status}

Changes of health status biomarkers in periparturient dairy goats are shown in Table 3. Compared with the CON group, biomarkers of health status were improved with BBR feeding. Supplementation with both BBR2 and BBR4 increased ( $p \leq 0.05$ ) plasma albumin and paraoxonase concentrations. Data showed that either BBR2 or BBR4 treatment reduced ( $p \leq 0.05$ ) plasma concentrations of cholesterol, haptoglobin, and ceruloplasmin, upon transition period. Also, bilirubin tended $(p=0.09)$ to decrease with increasing BBR supplementation. No significant effect $(p \geq 0.05)$ was observed on plasma glucose, whereas, supplementation of BBR2 or BBR4 increased $(p \leq 0.05)$ insulin concentration of transition does. Moreover, BBR2 and BBR4 reduced $(p \leq 0.05)$ the NEFA concentration in transition 
period, and a tendency $(p=0.10)$ was observed for decreased BHBA in goats fed BBR compared with CON.

Table 3. Effect of Berberine (BBR) supplementation on biomarkers of inflammation and health status in transition dairy Saanen goats ${ }^{1}$.

\begin{tabular}{|c|c|c|c|c|c|c|}
\hline \multirow{2}{*}{ Item $^{2}$} & \multicolumn{4}{|c|}{ Treat $^{3}$} & \multirow{2}{*}{ SEM $^{4}$} & \multirow{2}{*}{$p$ Values } \\
\hline & $\mathrm{CON}$ & BBR1 & BBR2 & BBR4 & & \\
\hline \multicolumn{7}{|l|}{ Inflammation } \\
\hline Albumin, mg/dL & $4.05^{b}$ & $4.22^{b}$ & $4.94^{\mathrm{a}}$ & $4.76^{\mathrm{a}}$ & 0.063 & $<0.001$ \\
\hline Cholesterol, mg/dL & $70.62^{\mathrm{a}}$ & $68.61^{a b}$ & $64.38^{b}$ & $64.80^{\mathrm{b}}$ & 1.433 & 0.041 \\
\hline Bilirubin, mg/dL & 0.30 & 0.28 & 0.23 & 0.25 & 0.019 & 0.091 \\
\hline Haptoglobin, g/L & $0.46^{\mathrm{a}}$ & $0.40^{\mathrm{a}}$ & $0.31^{b}$ & $0.29^{b}$ & 0.016 & 0.004 \\
\hline Ceruloplasmin, $\mu \mathrm{mol} / \mathrm{L}$ & $3.70^{\mathrm{a}}$ & $3.60^{\mathrm{ab}}$ & $3.30^{b}$ & $3.36^{\mathrm{b}}$ & 0.078 & 0.018 \\
\hline $\begin{array}{l}\text { Paraoxonase, } \mathrm{U} / \mathrm{mL} \\
\text { Energy balance }\end{array}$ & $125.90^{\mathrm{c}}$ & $126.71 \mathrm{bc}$ & $132.19^{a}$ & $131.14^{\mathrm{ab}}$ & 1.260 & 0.017 \\
\hline Glucose, mg/dL & 59.62 & 56.90 & 61.28 & 61.14 & 2.011 & 0.432 \\
\hline Insulin, $\mu / \mathrm{mL}$ & $19.40^{b}$ & $21.57^{b}$ & $26.27^{\mathrm{a}}$ & $27.13^{\mathrm{a}}$ & 0.905 & 0.001 \\
\hline Non-esterified fatty acids, $\mathrm{mmol} / \mathrm{L}$ & $0.16^{\mathrm{a}}$ & $0.15^{\mathrm{ab}}$ & $0.10^{\mathrm{b}}$ & $0.11^{b}$ & 0.012 & 0.028 \\
\hline$\beta$-hydroxybutyrate, mmol/L & 0.48 & 0.43 & 0.32 & 0.34 & 0.051 & 0.100 \\
\hline
\end{tabular}

${ }^{\mathrm{a}-\mathrm{c}}$ Within a row, means without a common uppercase superscript letter differ $(p<0.05) .{ }^{1}$ Values are leastsquare means. ${ }^{2}$ Data cover the last 21 days of gestation through the first 21 days of lactation. ${ }^{3} \mathrm{CON}=$ diet without BBR supplementation; BBR1, BBR2, BBR4 = diet supplemented with 1, 2, and $4 \mathrm{~g} / \mathrm{d}$ of BBR, respectively. ${ }^{4} \mathrm{SEM}=$ pooled standard error of mean.

\subsection{Colostrum and Milk Production and Components}

Colostrum and milk production are shown in Table 4. Supplementary BBR did not affect $(p \geq 0.05)$ colostrum and milk components. The highest $(p \leq 0.05)$ colostrum yield was observed in BBR2 group, followed by BBR4. Increased $(p \leq 0.05)$ milk yield was observed in both BBR2- and BBR4-fed goats.

Table 4. Effect of Berberine (BBR) supplementation on colostrum and milk performance of dairy Saanen goats ${ }^{1}$.

\begin{tabular}{|c|c|c|c|c|c|c|}
\hline \multirow{2}{*}{ Item $^{2}$} & \multicolumn{4}{|c|}{ Treat $^{3}$} & \multirow{2}{*}{ SEM $^{4}$} & \multirow{2}{*}{$p$ Values } \\
\hline & Control & BBR1 & BBR2 & BBR4 & & \\
\hline Colostrum & & & & & & \\
\hline Yield, $\mathrm{kg}$ / first 2 milkings & $0.80^{\mathrm{b}}$ & $1.20^{\mathrm{b}}$ & $1.62^{\mathrm{a}}$ & $1.40^{\mathrm{ab}}$ & 0.197 & 0.050 \\
\hline Protein, $\%$ & 9.41 & 8.22 & 9.13 & 8.10 & 0.914 & 0.680 \\
\hline Fat, \% & 9.83 & 8.75 & 7.01 & 7.82 & 1.783 & 0.596 \\
\hline Lactose, $\%$ & 4.01 & 4.15 & 4.10 & 4.19 & 0.123 & 0.743 \\
\hline Total solids, \% & 21.54 & 19.90 & 19.74 & 18.63 & 1.639 & 0.668 \\
\hline $\begin{array}{l}\text { Solid non-fat, \% } \\
\text { Milk }\end{array}$ & 13.77 & 12.87 & 13.73 & 12.93 & 0.790 & 0.725 \\
\hline Yield, kg/d & $1.70^{b}$ & $1.98^{a b}$ & $2.54^{\mathrm{a}}$ & $2.15^{\mathrm{a}}$ & 0.155 & 0.013 \\
\hline Protein, \% & 4.56 & 3.92 & 3.76 & 3.63 & 0.363 & 0.314 \\
\hline Fat, \% & 4.96 & 4.74 & 4.55 & 4.15 & 0.582 & 0.695 \\
\hline Lactose, \% & 3.94 & 4.47 & 4.52 & 4.70 & 0.253 & 0.227 \\
\hline Total solids, \% & 14.01 & 13.89 & 12.16 & 12.82 & 0.598 & 0.101 \\
\hline Solid non-fat, \% & 9.28 & 9.27 & 8.61 & 9.31 & 0.196 & 0.074 \\
\hline
\end{tabular}

${ }^{\mathrm{a}-\mathrm{b}}$ Within a row, means without a common uppercase superscript letter differ $(p<0.05) .{ }^{1}$ Values are leastsquare means. ${ }^{2}$ Data cover the last 21 days of gestation through the first 21 days of lactation. ${ }^{3} \mathrm{CON}=$ diet without BBR supplementation; BBR1, BBR2, BBR4 = diet supplemented with 1, 2, and $4 \mathrm{~g} / \mathrm{d}$ of BBR, respectively.

${ }^{4} \mathrm{SEM}=$ pooled standard error of mean . 


\subsection{Colostrum, Milk, and Blood Antioxidant Status}

Milk and blood TAC in the does supplemented with BBR2 and BBR4 was higher than in CON and BBR1 groups (Table 5, $p \leq 0.05$ ). Indeed, colostrum TAC represented the highest $(p \leq 0.05)$ value in BBR4, followed by BBR2 and BBR1. Likewise, BBR2- and BBR4-supplemented goats had lower $(p \leq 0.05)$ MDA concentration in colostrum and blood. The lowest $(p \leq 0.05)$ MDA in milk was observed in BBR2, followed by BBR4 and BBR1. In terms of enzymatic antioxidant, the activity of SOD in blood, colostrum, and milk were higher $(p \leq 0.05)$ in does supplemented with either BBR2 or BBR4. GSH-Px in colostrum and blood were increased $(p \leq 0.05)$ in BBR supplemented goats compared with control. Likewise, the GSH-Px activity in milk was higher $(p \leq 0.05)$ in BBR2 and BBR4 groups. The CAT activity in colostrum and blood of does supplemented with either BBR2 or BBR4 decreased $(p \leq 0.05)$ compared with the corresponding values of CON group. Similarly, the milk CAT activity increased $(p \leq 0.05)$ with either BBR2 or BBR4 supplementation during the transition period.

Table 5. Effect of Berberine (BBR) supplementation on antioxidant status of colostrum, milk, and blood in transition dairy Saanen goats ${ }^{1}$.

\begin{tabular}{|c|c|c|c|c|c|c|}
\hline \multirow{2}{*}{ Item ${ }^{2,3}$} & \multicolumn{4}{|c|}{ Treat 4} & \multirow{2}{*}{ SEM $^{5}$} & \multirow{2}{*}{$p$ Values } \\
\hline & CON & BBR1 & BBR2 & BBR4 & & \\
\hline \multicolumn{7}{|l|}{ Blood } \\
\hline $\mathrm{TAC}, \mathrm{mmol} / \mathrm{L}$ & $0.26^{b}$ & $0.28^{b}$ & $0.34^{\mathrm{a}}$ & $0.34^{\mathrm{a}}$ & 0.012 & 0.002 \\
\hline $\mathrm{MDA}, \mathrm{nmol} / \mathrm{L}$ & $1.76^{\mathrm{a}}$ & $1.60^{\mathrm{a}}$ & $1.32^{b}$ & $1.34^{\mathrm{b}}$ & 0.110 & 0.050 \\
\hline SOD, U/g Hb & $1498.16^{b}$ & $1555.30^{b}$ & $1771.22^{\mathrm{a}}$ & $1725.20^{a}$ & 47.301 & 0.009 \\
\hline GSH-Px, U/g Hb & $39.95^{b}$ & $42.15^{\mathrm{a}}$ & $46.68^{\mathrm{a}}$ & $44.34^{\mathrm{a}}$ & 1.421 & 0.048 \\
\hline $\begin{array}{c}\text { CAT, U/g Hb } \\
\text { Colostrum }\end{array}$ & $17.68^{b}$ & $21.34^{a b}$ & $25.94^{\mathrm{a}}$ & $27.52^{a}$ & 2.350 & 0.050 \\
\hline $\mathrm{TAC}, \mathrm{mmol} / \mathrm{L}$ & $1.07^{\mathrm{C}}$ & $1.15^{b c}$ & $1.42^{a b}$ & $1.51^{\mathrm{a}}$ & 0.081 & 0.014 \\
\hline $\mathrm{MDA}, \mathrm{nmol} / \mathrm{L}$ & $2.50^{\mathrm{a}}$ & $2.27^{\mathrm{ab}}$ & $1.90^{b}$ & $1.95^{b}$ & 0.134 & 0.044 \\
\hline SOD, U/mL & $22.73^{b}$ & $24.4^{\mathrm{ab}}$ & $26.9^{a}$ & $26.57^{\mathrm{a}}$ & 0.814 & 0.021 \\
\hline GSH-Px, U/mL & $59.34^{b}$ & $63.68^{a b}$ & $77.00^{\mathrm{a}}$ & $73.00^{\mathrm{a}}$ & 3.912 & 0.041 \\
\hline $\begin{array}{c}\text { CAT, U/mL } \\
\text { Milk }\end{array}$ & $15.75^{b}$ & $17.43^{\mathrm{ab}}$ & $22.23^{\mathrm{a}}$ & $21.08^{a}$ & 1.490 & 0.047 \\
\hline $\mathrm{TAC}, \mathrm{mmol} / \mathrm{L}$ & $1.26^{\mathrm{b}}$ & $1.37^{b}$ & $1.67^{\mathrm{a}}$ & $1.65^{\mathrm{a}}$ & 0.064 & 0.003 \\
\hline $\mathrm{MDA}, \mathrm{nmol} / \mathrm{L}$ & $3.24^{\mathrm{a}}$ & $2.97^{\mathrm{ab}}$ & $2.41^{\mathrm{c}}$ & $2.52^{b c}$ & 0.122 & 0.004 \\
\hline SOD, U/mL & $23.87^{c}$ & $25.31^{\mathrm{bc}}$ & $29.01^{a}$ & $28.73^{a b}$ & 1.291 & 0.050 \\
\hline GSH-Px, U/mL & $74.89^{b}$ & $83.78^{b}$ & $97.34^{\mathrm{a}}$ & $82.17^{\mathrm{a}}$ & 2.54 & 0.005 \\
\hline CAT, U/mL & $20.17^{b}$ & $21.93^{b}$ & $27.35^{\mathrm{a}}$ & $27.21^{\mathrm{a}}$ & 1.342 & 0.011 \\
\hline
\end{tabular}

${ }^{a-c}$ Within a row, means without a common uppercase superscript letter differ $(p<0.05)$. ${ }^{1}$ Values are leastsquare means. ${ }^{2}$ Data cover the last 21 days of gestation through the first 21 days of lactation. ${ }^{3}$ TAC $=$ total antioxidant capacity, $\mathrm{MDA}=$ malondialdehyde, $\mathrm{SOD}=$ superoxide dismutase, $\mathrm{GSH}-\mathrm{Px}=$ glutathione peroxidase, $\mathrm{CAT}=$ catalase. ${ }^{4} \mathrm{CON}=$ diet without BBR supplementation; BBR1, BBR2, BBR4 = diet supplemented with 1,2 , and $4 \mathrm{~g} / \mathrm{d}$ of BBR, respectively. ${ }^{5} \mathrm{SEM}=$ pooled standard error of mean.

\subsection{Colostrum and Milk Fatty Acid Profile}

The goats' colostrum and milk FA profile are presented in Table 6. Supplementation of BBR2 and BBR4 increased concentrations of de novo FA in colostrum and milk $(p \leq 0.05)$. Supplementation of BBR to transition goats reduced performed FA in colostrum $(p=0.02)$ and milk $(p=0.04)$ fat in BBR4, followed by BBR2 as compared to the CON diet. FFA concentration in colostrum and milk fat was decreased in goats receiving either BBR2 or BBR4 compared to the CON diet $(p \leq 0.05)$. The concentration of SFAs in colostrum and milk fat were increased $(p \leq 0.05)$ with BBR2 and BBR4, while USFAs were decreased in milk $(p \leq 0.05)$. In the present study, although the concentration of MUFAs in colostrum was reduced with BBR2 and BBR4 supplementation, PUFAs were not affected in either colostrum or milk $(p \geq 0.05)$. The content of C18:0 in colostrum increased ( $p \leq 0.05)$ compared with the CON diet when BBR2 and BBR4 were supplemented for transition 
goats. In addition, both BBR2 and BBR4 decreased $(p \leq 0.05)$ the percentage of C18:1n9 (oleic acid) in colostrum, with the greatest decline being for the BBR2 group.

Table 6. Effect of Berberine (BBR) supplementation on colostrum and milk fatty acid profile of dairy Saanen goats ${ }^{1}$.

\begin{tabular}{|c|c|c|c|c|c|c|}
\hline \multirow{2}{*}{ Item $^{2,3}$} & \multicolumn{4}{|c|}{ Treat $^{4}$} & \multirow{2}{*}{ SEM $^{5}$} & \multirow{2}{*}{$p$ Values } \\
\hline & CON & BBR1 & BBR2 & BBR4 & & \\
\hline \multicolumn{7}{|l|}{ Colostrum } \\
\hline De novo fatty acids, $\%$ & $32.63^{b}$ & $32.50^{b}$ & $39.52^{\mathrm{a}}$ & $38.22^{\mathrm{a}}$ & 1.414 & 0.007 \\
\hline Mixed fatty acids, \% & 26.18 & 30.51 & 28.50 & 32.12 & 2.855 & 0.637 \\
\hline Preformed fatty acids, $\%$ & $40.19^{\mathrm{a}}$ & $36.77^{a b}$ & $31.90^{\mathrm{b}}$ & $29.66^{b}$ & 2.244 & 0.025 \\
\hline FFA, meq $/ 100 \mathrm{~g}$ fat & $15.37^{\mathrm{a}}$ & $14.90^{\mathrm{a}}$ & $10.35^{\mathrm{b}}$ & $11.03^{\mathrm{b}}$ & 0.826 & 0.001 \\
\hline SFA, $\%$ & $61.70^{b}$ & $63.82^{a b}$ & $69.20^{\mathrm{a}}$ & $69.55^{a}$ & 1.910 & 0.030 \\
\hline UFA, \% & 23.51 & 22.31 & 18.19 & 19.10 & 2.348 & 0.359 \\
\hline MUFA, \% & $14.30^{\mathrm{a}}$ & $16.77^{\mathrm{a}}$ & $8.44^{b}$ & $9.91 \mathrm{ab}$ & 1.900 & 0.032 \\
\hline PUFA, \% & 6.73 & 5.53 & 5.74 & 5.14 & 0.501 & 0.283 \\
\hline $\mathrm{C} 16: 0, \%$ & 21.84 & 19.77 & 20.02 & 21.73 & 1.075 & 0.411 \\
\hline $\mathrm{C} 18: 0, \%$ & $7.72^{\mathrm{a}}$ & $6.15^{\mathrm{ab}}$ & $4.24^{\mathrm{b}}$ & $3.57^{\mathrm{b}}$ & 0.824 & 0.016 \\
\hline C18:1 c9, \% & $12.73^{a}$ & $14.93^{\mathrm{a}}$ & $5.97^{b}$ & $7.96^{\mathrm{ab}}$ & 1.890 & 0.020 \\
\hline $\begin{array}{c}\text { Milk } \\
\text { De novo fatty acids, \% }\end{array}$ & $38.02^{\mathrm{a}}$ & $38.46^{\mathrm{ab}}$ & $39.77 \mathrm{ab}$ & $41.03^{b}$ & 0.831 & 0.050 \\
\hline Mixed fatty acids, $\%$ & 34.09 & 40.08 & 38.19 & 38.60 & 1.646 & 0.114 \\
\hline Preformed fatty acids, $\%$ & $27.88^{\mathrm{a}}$ & $21.47^{\mathrm{ab}}$ & $21.25^{a b}$ & $20.27^{b}$ & 1.857 & 0.049 \\
\hline FFA, meq $/ 100 \mathrm{~g}$ fat & $10.85^{\mathrm{a}}$ & $9.54^{\mathrm{a}}$ & $6.51^{\mathrm{b}}$ & $6.98^{b}$ & 0.540 & 0.003 \\
\hline $\mathrm{SFA}, \%$ & $64.97^{b}$ & $65.17^{b}$ & $69.65^{a}$ & $70.02^{a}$ & 1.01 & 0.045 \\
\hline UFA, \% & $21.84^{\mathrm{a}}$ & $19.88^{\mathrm{a}}$ & $18.28^{a b}$ & $17.29^{b}$ & 1.06 & 0.049 \\
\hline MUFA, \% & $14.54^{\mathrm{a}}$ & $15.73^{\mathrm{a}}$ & $12.61^{b}$ & $12.02^{b}$ & 0.623 & 0.004 \\
\hline PUFA, \% & 4.03 & 4.12 & 3.90 & 3.92 & 0.599 & 0.901 \\
\hline $\mathrm{C} 16: 0, \%$ & 29.38 & 28.83 & 29.56 & 29.19 & 0.940 & 0.796 \\
\hline $\mathrm{C} 18: 0, \%$ & 8.04 & 7.40 & 6.96 & 5.84 & 1.171 & 0.612 \\
\hline C18:1 c9, \% & 14.84 & 14.58 & 10.66 & 10.77 & 1.373 & 0.081 \\
\hline
\end{tabular}

${ }^{\mathrm{a}-\mathrm{b}}$ Within a row, means without a common uppercase superscript letter differ $(p<0.05) .{ }^{1}$ Values are leastsquare means. ${ }^{2}$ Data cover the first $21 \mathrm{~d}$ of lactation. ${ }^{3}$ FFA = free fatty acids; SFA = saturated fatty acids; UFA = unsaturated fatty acids; MUFA = mono-unsaturated fatty acids; PUFA = poly-unsaturated fatty acids. ${ }^{4} \mathrm{CON}=$ diet without BBR supplementation; BBR1, BBR2, BBR4 = diet supplemented with 1,2, and $4 \mathrm{~g} / \mathrm{d}$ of BBR, respectively. ${ }^{5} \mathrm{SEM}=$ pooled standard error of mean.

\section{Discussion}

The transition period imposes tremendous stress on dairy goats and is recognized as a critical period because of anatomical, physiological, biochemical, and hormonal alterations that lead to metabolic, immune, and antioxidant imbalance, which can result in inflammation [1,3] and oxidative stress [8,9], and may result in inadequate nutrient and energy intake to support the onset of lactation [1-3], similar to dairy cows $[4,5,7,10]$. In this study, we determined whether BBR supplementation would modulate the colostrum and milk production of transition Saanen goats, as well as their antioxidant status. Not only are there scarce data available on performance, milk, and colostrum antioxidants and adaptive response indices of transition goats [1], but also, no investigation has evaluated the BBR effect on dairy ruminants, especially transition goats. Hence, to the best of our knowledge, this is the first study exploring changes in colostrum and milk antioxidants and FA profile of transition dairy goats.

\subsection{Dry Matter Intake, Body Condition Score, and Energy Balance}

Transition from late gestation to early lactation is a stressful period that is faced by the vast majority of dairy animals with NEB [3]. It is well-established that dairy goats are nutritionally challenged in this phase, with increasing energy requirements and the limitation of voluntary feed intake that make periparturient goats vulnerable to 
metabolic diseases [1-3]. Thus, the need for finding alternatives to mitigate NEB and improve performance has great importance for transition dairy animals [34]. With regard to performance, DMI, BW, and BCS were in line with earlier findings from transition dairy goats $[3,35]$. In this study, we found that supplementing 2 or $4 \mathrm{~g}$ BBR/d (BBR2 and BBR 4, respectively), increased DMI, as well as the intake of NEL, MP, and EB in transition goats. Lima et al. [36] reported that hormone-induced adaptations in transition cattle lead to reduction in DMI and serious imbalances in energy status. In addition, a positive correlation between DMI and intakes of NEL and MP, as well as EB, has been reported in goats [36] and cows [37]. Thus, our data suggest potential involvement of BBR supplementation in improving DMI and EB via the inhibition of excess body fat mobilization in periparturient goats.

In agreement with current findings, our recent report using the same animal cohort [21] revealed that BBR ingestion in transition goats enhanced pre- and post-partum intakes of $\mathrm{DM}$ and NEL. Likewise, it has been reported that BBR enhances energy homeostasis via AMP-activated protein kinase (AMPK) activation [16,38-40]. AMPK, an AMP-dependent protein kinase, is a critical molecule in the regulation of bioenergetic metabolism and metabolic-related diseases [16,40]. In line with our study, numerous reports $[16,40,41]$ retrieved from both in vivo and ex vivo studies have shown that BBR can improve energy homeostasis.

Collard et al. [42] reported that a decrease in BCS is evidence of tissue mobilization in severe cases of NEB in transition cows; similarly, a recent study [3] verified BCS as an indicator of body fat reserve usage. De Vries and Veerkamp [43] reported that BCS losses are correlated with fat mobilization, and therefore, BCS might be used as indicator for EB during the transition period. Thus, in the present study, the tendency to increase BCS of both BBR2 and BBR4 supplemented goats is another confirmation of enhanced energy homeostasis in these groups. Taken together, the use of BBR in transition goats may prevent NEB.

\subsection{Biomarkers of Inflammation and Health Status}

It is well-established that NEB and particular indicators of lipolysis, such as NEFA and $\mathrm{BHB}$, are implicated in immuno-suppressive and inflammation-modulating effects [1,4]. Similar to that of cows [5], the NEB in transition goats is characterized by lower blood glucose levels and elevated blood concentrations of NEFA and BHBA [3], which is consistent with the present study. Interestingly, supplementation of either BBR2 or BBR4 (i.e., 2 and $4 \mathrm{~g}$ BBR per day) increased plasma albumin and paraoxonase concentrations, while reducing fat mobilization indicators (NEFA and BHBA) and inflammation biomarkers (haptoglobin and ceruloplasmin), which demonstrated the potential alleviative effect of BBR on fat metabolism disorder and inflammation initiated by NEB in periparturient goats.

In this study, plasma from BBR-supplemented goats had an increased concentration of negative APP and decreased levels of the positive APP, which agrees with in vitro studies in mouse neuroblastoma N18TG2 cell line [44] and in human neuroblastoma SH-SY5Y cells [45]. Li et al. [19] have demonstrated the anti-inflammatory effect of BBR associated with alleviation of the APP and proinflammatory cytokines. Similarly, Wang et al. [17] reported that BBR inhibited inflammation by regulating different signaling pathways and cytokines. In addition, the expression of pro-inflammatory genes in the adipose tissue in obese mice was inhibited by BBR, which indicated that BBR moderates both the acute and low-grade inflammatory responses [38]. One possible mechanism for the anti-inflammatory effect of BBR may be through activated protein kinase activation. Jeong et al. [38] reported that $B B R$ represses pro-inflammatory responses through activated protein kinase activation in macrophages and significantly down-regulates the expression of pro-inflammatory genes. Further studies should consider analyzing the expression of genes related to inflammation when BBR is supplemented in transition dairy goats.

Serum values of glucose, insulin, and NEFA from this study indicated the occurrence of body fat mobilization in transition dairy goats. The BBR administration increased serum 
insulin concentrations and reduced NEFA and BHBA in transition goats, which implies its potential capacity for ameliorating fat mobilization. Similar to these results, Zamuner et al. [46] reported that reduction in NEFA and BHBA concentrations, as well as accretion in insulin and glucose, indicated increased body reserve usage and NEB. In this study, the decreases of plasma NEFA and the tendency of BHBA reflected the mitigated mobilization of body fat $[4,5,46]$ in BBR-supplemented goats.

\subsection{Colostrum and Milk Performance and Components}

In the current study, the positive effect of BBR on colostrum and milk yields could be due to the higher DMI and EB in goats receiving the supplemental BBR [6,23]. Positive associations between transition energy status and subsequent production in goats have been reported in numerous studies [35,36]. In line with our results, van Knegsel et al. [47] showed that, when energy demands for milk production are fulfilled by feed intake, this leads to improved EB and reduced body fat mobilization, resultant in higher milk production.

The higher colostrum and milk yields could also be attributed to the anti-inflammatory role of the BBR since increments in indicators of inflammatory status, have consistently been linked to poor performance in dairy goats $[1,8,9]$; however, most data on this effect have been collected in dairy cows [4-7]. Indeed, the impact of metabolic inflammation on production has been shown, of which cows with higher levels of inflammatory markers had reduced milk production in the first month, compared to cows presenting lower levels of inflammation [10]. Farney et al. [48] showed that the anti-inflammatory treatment of transition cows increased milk yield by about 7\%. All this shows that, since DMI is a major factor limiting colostrum and milk production in early lactation $[1,4,5]$, enhanced DMI in goats that received supplemental BBR2 and BBR4 along with mitigated inflammation leads to higher intakes of NEL and MP, which results in better colostrum and milk yields of goats.

\subsection{Colostrum, Milk, and Blood Antioxidant Status}

Studies performed in the last decade clearly indicate that dairy goats [8,9] experience oxidative stress (OS) in the transition period, as do cows [7]. Colostrum and milk fat of goats is very susceptible to oxidation [49], which is a major deteriorative reaction that occurs during the processing, distribution, and storage of milk and dairy products, and, moreover, it can cause chemical changes that affect the nutritional quality, integrity, and safety of the milk $[49,50]$. In addition, given that colostrum is the first meal that a kid should receive shortly after birth, its antioxidant content is important to offsetting birth-associated OS [7-9]. The antioxidative properties of colostrum and milk could be attributed to the presence of enzymes, such as GSH-Px, SOD, and CAT [49-51]. There are many studies on the positive relationship between the blood and milk antioxidant status [49,52]. The current results showed that, compared with CON, plasma, colostrum, and milk TAC increased with BBR2 and BBR4. In addition, MDA concentration in either plasma or colostrum and milk decreased with BBR supplementation. This finding is similar to earlier findings $[16,18,20]$ where BBR was reported to reduce free radicals and exert radical scavenging activity. Moghaddam et al. [20] reported that BBR significantly decreases serum MDA and increases TAC in alloxan-induced diabetic rats. In line with our findings, Malekinezhad et al. [53] showed that BBR supplementation restored the level of MDA in aflatoxin-B1- and ochratoxin-contaminated broilers. In addition, it has been reported that feeding goats with Berberis vulgaris leaf (a natural rich source of BBR) leads to greater TAC [54].

In the current study, the overall increase in enzymatic antioxidants of blood, colostrum, and milk with BBR supplementation in transition dairy goats, in particular BBR2 and BBR4, is in line with previous studies on the antioxidant effects of BBR supplementation. As such, the antioxidant effect of supplementation of 50 and $100 \mathrm{mg} \mathrm{BBR} / \mathrm{kg} /$ day (the dose corresponding with BBR2 and BBR4, respectively) has been corroborated by studying its inhibitory effect on the up-regulation of glial fibrillary acidic protein (GFAP), a key indicator of astrogliosis which occurs as a result of oxidative stress in diabetic rats [20]. 
BBR enhanced the activity of antioxidant enzymes both in vitro and in vivo $[17,20,53]$. In addition, BBR significantly improved enzymatic antioxidants, such as SOD, CAT, and GSH-Px, in azoxymethane-induced carcinogenic rats [55]. Another study showed that BBR restores the activity of SOD in rats with type-1 diabetes mellitus [16]. Investigation on antioxidants, GSH-Px, and SOD enzymes concluded that BBR restored the levels of both SOD and GSH-Px, thereby reducing the elevated levels of lipid peroxidation in diabetic rats [41]. In the current study, the superior antioxidant properties of the blood, colostrum, and milk of BBR-supplemented goats suggest that BBR could prevent oxidative stress in transition goats.

\subsection{Colostrum and Milk Fatty Acid Profile}

As in cows [11-13], in dairy goats, milk FA are related to the stage of lactation, and that relates to energy balance [14]. Milk FA originate directly from the diet, from de novo synthesis in the mammary gland, from formation in the rumen by biohydrogenation or bacterial degradation, and from the release from body fat stores [56].

Negative energy balance leads to greater proportions of SFAs, mainly C16:0 and C18:0; therefore, using milk FA as an indicator for the metabolic status of lactating animals could be an indirect method for monitoring energy status $[15,56]$. This agrees with our results showing that supplementation with BBR2 and BBR4 increased the concentrations of de novo FA in colostrum and milk and had a tendency to increase mixed FA. Van Knegsel et al. [47] suggested that, during NEB, de novo synthesis of FA (C6:0 to C14:0) was reduced and body fat reserves were used. Hence, the promoted de novo milk FA in BBR-supplemented goats was probably due to their EB, which may lead to increased de novo FA synthesis in colostrum and milk as a result of less body fat reserve usage. Therefore, in the present study, the increased SCFA concentrations in both the colostrum and milk from the BBR2 and BBR4 groups are likely due to improved energy balance.

Likewise, the decline in de novo and mixed FA of the CON group indicated an increase in fat mobilization from reserves during early lactation, which was mitigated by BBR supplementation. This is in agreement with Bionaz et al. [56], who reported that the high uptake of long-chain FA by mammary gland tissue inhibits de novo synthesis of FA through the inhibition of acetyl-coenzyme a carboxylase. It has been shown [11] that about half of the mixed FA originates from de novo synthesis. Similarly, Woolpert et al. [27] reported an increase in mixed FA concentration following increases in de novo FA. Therefore, this could be a possible explanation for a tendency to increase mixed FA in BBR-fed goats.

In the current study, preformed FA concentrations (sum of FA > C16) were decreased in BBR2 and BBR4 as a result of enhanced EB, with a similar pattern described by Kay et al. [12] who reported that the preformed fatty acids were decreased with lactation progress and improvement in EB. Similarly, Gross et al. [11] declared that de novo and preformed FA reflected changes in the energy balance of dairy cows. In addition, Ducháček et al. [15] reported that Holstein cows in NEB had lower SFA and higher unsaturated fatty acid (UFA) milk contents, which agrees with our results, suggesting that goats with lower EB produced colostrum and milk with a higher content of UFA.

Strzałkowska et al. [14] reported that the FFA level is an indicator of EB in goat milk. A NEB occurring during the early stage of lactation leads to lipolysis of adipose tissue, which simultaneously increases FFA in goat's milk [14]. Similarly, our results confirmed that improved EB in goats that received supplemental BBR was associated with a decrease in FFA. This also agrees with Stoop et al. [13], who reported that milk SFAs decrease, while MUFAs, mainly represented by C18:1 c 9 decrease with improved energy balance.

In line with our results, Bionaz et al. [56] reported that excessive amounts of NEFA, released during body fat mobilization, are also transferred to milk, resulting in increased contents of milk long-chain FA, such as C18:1 c9 and C18:0. Hence, lower C18:1n-9 and C18:0 concentrations in colostrum and milk from either BBR2 or BBR4 might be linked to enhanced EB. It is well-established that oleic acid (C18:1 c9) is the predominant FA 
in adipocytes, which is primarily released through lipolysis during NEB [11,15]. Gross et al. [11] reported that an elevated proportion of C18:1 c9 in milk fat is a suitable biomarker for NEB. This was also confirmed by Gross et al. [11], who reported that in early-lactating cows with NEB, there is a decrease in short-chain FA and an increase in long-chain FAs. Moreover, increases of C18:1 c9 often occur at the expense of de novo FA in milk fat when cows increase their mobilization of body fat reserves [11,15]. In dairy goats, the increase in relative percentage of C18:1 c9 has been reported during periods of NEB [57].

\section{Conclusions}

In summary, supplementation with BBR during the transition period can increase DMI EB, intakes of NEL and MP, and reduce plasma biochemical indicators of NEB and plasma biomarkers of inflammation (positive APPs) in dairy goats. Supplementation with BBR increased colostrum and milk yields, as well as improving antioxidant indicators in blood, colostrum, and milk, demonstrating its potential positive effect on productivity, immunity, and antioxidative capacity in transition dairy goats. Overall, our findings suggest that supplementation of 2 and/or 4 g/d BBR (i.e., 50 and/or $100 \mathrm{mg}$ BBR per $\mathrm{kg} \mathrm{BW)} \mathrm{may}$ enhance $\mathrm{EB}$ and improve performance in transition dairy goats.

Author Contributions: Conceptualization, N.G. and M.H.F.N.; methodology, N.G. and M.H.F.N.; validation, N.G., M.H.F.N., S.H.F. and E.V.-B.-P.; formal analysis, N.G., S.H.F. and S.E.G.; investigation, N.G.; data curation, N.G. and S.H.F.; writing—original draft preparation, N.G.; writing-review and editing, N.G., M.H.F.N., E.V.-B.-P. and S.E.G.; visualization, N.G.; supervision, M.H.F.N. All authors have read and agreed to the published version of the manuscript.

Funding: This work was supported by a grant from the Iran National Science Foundation for project no. 97009560

Institutional Review Board Statement: The study was conducted in accordance with the ethical guidelines of the Iranian Council of Animal Care (1993) on the protection of animals used for scientific purposes and approved by the Animal Welfare and Ethical Review Board of the Department of Animal Science, University of Birjand (ID project 5506).

Informed Consent Statement: Informed consent was obtained from the farm owners that involved in the study.

Data Availability Statement: All of the required data have been presented in our article.

Acknowledgments: The authors would like to thank Iman Barani for his valuable assistance.

Conflicts of Interest: The authors confirm that there are no conflict of interest to declare.

\section{References}

1. Tosto, M.S.L.; Santos, S.A.; da Costa Pinto Filho, R.; de Carvalho Rodrigues, T.C.G.; Nicory, I.M.C.; de Carvalho, G.G.P.; de Jesus Pereira, T.C. Metabolic and behavior changings during the transition period as predictors of calving proximity and welfare of dairy goats. Vet. Anim. Sci. 2021, 11, 100-168. [CrossRef] [PubMed]

2. Zamuner, F.; Cameron, A.W.N.; Carpenter, E.K.; Leury, B.J.; DiGiacomo, K. Endocrine and metabolic responses to glucose, insulin, and adrenocorticotropin infusions in early-lactation dairy goats of high and low milk yield. J. Dairy Sci. 2020, 103, 12045-12058. [CrossRef] [PubMed]

3. Zamuner, F.; DiGiacomo, K.; Cameron, A.W.N.; Leury, B.J. Endocrine and metabolic status of commercial dairy goats during the transition period. J. Dairy Sci. 2020, 103, 5616-5628. [CrossRef] [PubMed]

4. Esposito, G.; Irons, P.C.; Webb, E.C.; Chapwanya, A. Interactions between negative energy balance, metabolic diseases, uterine health and immune response in transition dairy cows. Anim. Reprod. Sci. 2014, 144, 60-71. [CrossRef] [PubMed]

5. Sun, B.F.; Cao, Y.C.; Cai, C.J.; Chao, Y.U.; Li, S.X.; Yao, J.H. Temporal dynamics of nutrient balance, plasma biochemical and immune traits, and liver function in transition dairy cows. J. Integr. Agric. 2020, 19, 820-837. [CrossRef]

6. Humblet, M.F.; Guyot, H.; Boudry, B.; Mbayahi, F.; Hanzen, C.; Rollin, F.; Godeau, J.M. Relationship between haptoglobin, serum amyloid A, and clinical status in a survey of dairy herds during a 6-month period. Vet. Clin. Pathol. 2006, 35, 188-193. [CrossRef]

7. Abuelo, A.; Hernández, J.; Benedito, J.L.; Castillo, C. Redox biology in transition periods of dairy cattle: Role in the health of periparturient and neonatal animals. Antioxidants 2019, 8, 20-29. [CrossRef]

8. Celi, P.; Di Trana, A.; Claps, S. Effects of plane of nutrition on oxidative stress in goats during the peripartum period. Vet. J. 2010, 184, 95-99. [CrossRef] 
9. Karapehlivan, M.; Kaya, I.; Sag, A.; Akin, S.; Ozcan, A. Effects of early and late lactation period on plasma oxidant/antioxidant balance of goats. Kafkas. Univ. Vet. Fak. Derg. 2013, 19, 529-533.

10. Trevisi, E.; Minuti, A. Assessment of the innate immune response in the periparturient cow. Res. Vet Sci. 2018, 116, 47-54. [CrossRef]

11. Gross, J.J.; van Dorland, H.A.; Bruckmaier, R.; Schwarz, F.J. Milk fatty acid profile related to energy balance in dairy cows. J Dairy Res. 2011, 78, 479-488. [CrossRef] [PubMed]

12. Kay, J.K.; Weber, W.J.; Moore, C.E.; Bauman, D.E.; Hansen, L.B.; Chester-Jones, H.; Baumgard, L.H. Effects of week of lactation and genetic selection for milk yield on milk fatty acid composition in Holstein cows. J. Dairy Sci. 2005, 88, 3886-3893. [CrossRef]

13. Stoop, W.M.; Bovenhuis, H.; Heck, J.M.L.; Van Arendonk, J.A.M. Effect of lactation stage and energy status on milk fat composition of Holstein-Friesian cows. J. Dairy Sci. 2009, 92, 1469-1478. [CrossRef] [PubMed]

14. Strzałkowska, N.; Jóźwik, A.; Bagnicka, E.; Krzyżewski, J.; Horbańczuk, K.; Pyzel, B.; Horbańczuk, J.O. Chemical composition, physical traits and fatty acid profile of goat milk as related to the stage of lactation. Anim. Sci. Pap. 2009, 27, 311-320.

15. Ducháček, J.; Stádník, L.; Ptáček, M.; Beran, J.; Okrouhla, M.; Čítek, J.; Stupka, R. Effect of cow energy status on the hypercholesterolaemic fatty acid proportion in raw milk. Czech J. Food Sci. 2014, 32, 273-279. [CrossRef]

16. Ilyas, Z.; Perna, S.; Al-Thawadi, S.; Alalwan, T.A.; Riva, A.; Petrangolini, G.; Rondanelli, M. The effect of Berberine on weight loss in order to prevent obesity: A systematic review. Biomed. Pharmacother. 2020, 127, 110137. [CrossRef]

17. Wang, Y.; Liu, Y.; Du, X.; Ma, H.; Yao, J. The anti-cancer mechanisms of berberine: A review. Cancer Manag. Res. 2020, 12, 695. [CrossRef]

18. Wang, Y.; Yi, X.; Ghanam, K.; Zhang, S.; Zhao, T.; Zhu, X. Berberine decreases cholesterol levels in rats through multiple mechanisms, including inhibition of cholesterol absorption. Metabolism 2014, 63, 1167-1177. [CrossRef]

19. Li, Z.; Geng, Y.N.; Jiang, J.D.; Kong, W.J. Antioxidant and anti-inflammatory activities of berberine in the treatment of diabetes mellitus. Evid.-Based Complement. Altern. Med. 2014, 289264. [CrossRef]

20. Moghaddam, H.K.; Baluchnejadmojarad, T.; Roghani, M.; Khaksari, M.; Norouzi, P.; Ahooie, M.; Mahboobi, F. Berberine ameliorate oxidative stress and astrogliosis in the hippocampus of STZ-induced diabetic rats. Mol. Neurobiol. 2014, 49, 820-826. [CrossRef]

21. Ghavipanje, N.; Fathi Nasri, M.H.; Farhangfar, S.H.; Ghiasi, S.E.; Vargas-Bello-Pérez, E. Regulation of Nutritional Metabolism in Transition Dairy Goats: Energy Balance, Liver Activity, and Insulin Resistance in Response to Berberine Supplementation. Animals 2021, 11, 22-36. [CrossRef] [PubMed]

22. Iranian Council of Animal Care. Guide to the Care and Use of Experimental Animals; Isfahan University of Technology: Isfahan, Iran, 1995; Volume 1.

23. National Research Council, Committee on the Nutrient Requirements of Small Ruminants, Board on Agriculture, Division on Earth \& Life Studies. Nutrient Requirements of Small Ruminants: Sheep, Goats, Cervids, and New World Camelids; The National Academies Press: Washington, DC, USA, 2007.

24. Ferré, N.; Camps, J.; Prats, E.; Vilella, E.; Paul, A.; Figuera, L.; Joven, J. Serum paraoxonase activity: A new additional test for the improved evaluation of chronic liver damage. Clin. Chem. 2002, 48, 261-268. [CrossRef] [PubMed]

25. Kaylegian, K.E.; Lynch, J.M.; Fleming, J.R.; Barbano, D.M. Influence of fatty acid chain length and unsaturation on mid-infrared milk analysis. J. Dairy Sci. 2009, 92, 2485-2501. [CrossRef] [PubMed]

26. Association of Official Analytical Chemists. Official Methods of Analysis. Official Methods of Analysis of AOAC International; Association of Official Analytical Chemists: Arington, VA, USA, 2000.

27. Woolpert, M.E.; Dann, H.M.; Cotanch, K.W.; Melilli, C.; Chase, L.E.; Grant, R.J.; Barbano, D.M. Management, nutrition, and lactation performance are related to bulk tank milk de novo fatty acid concentration on northeastern US dairy farms. J. Dairy Sci. 2016, 99, 8486-8497. [CrossRef] [PubMed]

28. Wojciechowski, K.L.; Barbano, D.M. Prediction of fatty acid chain length and unsaturation of milk fat by mid-infrared milk analysis. J. Dairy Sci. 2016, 99, 8561-8570. [CrossRef]

29. Placer, Z.A.; Cushman, L.L.; Johnson, B. Estimation of product of lipid peroxidation (malonyl dialdehyde) in biochemical systems. Anal. Biochem. 1966, 16, 359-364. [CrossRef]

30. Benzie, I.F.; Strain, J.J. The ferric reducing ability of plasma (FRAP) as a measure of "antioxidant power": The FRAP assay. Anal. Biochem. 1996, 239, 70-76. [CrossRef]

31. Smet, K.; Raes, K.; De Block, J.; Herman, L.; Dewettinck, K.; Coudijzer, K. A change in antioxidative capacity as a measure of onset to oxidation in pasteurized milk. Int. Dairy J. 2008, 18, 520-530. [CrossRef]

32. Villaquiran, M.; Gipson, T.A.; Merkel, R.C.; Goetsch, A.L.; Sahlu, T. Body Condition Scores in Goats; American Institute for Goat Research, Langston University: Langston, OK, USA, 2004.

33. SAS Institute. STAT User's Guide: Statistics, Version 9.1; Statistical Analysis System Institute, Inc.: Cary, NC, USA, 2007.

34. Folnožić, I.; Turk, R.; Đuričić, D.; Vince, S.; Pleadin, J.; Flegar-Meštrić, Z.; Samardžija, M. Influence of body condition on serum metabolic indicators of lipid mobilization and oxidative stress in dairy cows during the transition period. Reprod. Domest. Anim. 2015, 50, 910-917. [CrossRef]

35. Pinotti, L.; Campagnoli, A.; D’ambrosio, F.; Susca, F.; Innocenti, M.; Rebucci, R.; Baldi, A. Rumen-protected choline and vitamin E supplementation in periparturient dairy goats: Effects on milk production and folate, vitamin B12 and vitamin E status. Animal 2008, 2, 1019-1027. [CrossRef] 
36. Douhard, F.; Friggens, N.C.; Tessier, J.; Martin, O.; Tichit, M.; Sauvant, D. Characterization of a changing relationship between milk production and liveweight for dairy goats undergoing extended lactation. J. Dairy Sci. 2013, 96, 5698-5711. [CrossRef] [PubMed]

37. Lima, F.S.; Sá Filho, M.F.; Greco, L.F.; Santos, J.E.P. Effects of feeding rumen-protected choline on incidence of diseases and reproduction of dairy cows. Vet. J. 2012, 193, 140-145. [CrossRef] [PubMed]

38. Jeong, H.W.; Hsu, K.C.; Lee, J.W.; Ham, M.; Huh, J.Y.; Shin, H.J.; Kim, J.B. Berberine suppresses proinflammatory responses through AMPK activation in macrophages. Am. J. Physiol. Endocrinol. 2009, 296, E955-E964. [CrossRef] [PubMed]

39. Dong, Z.H.; Lin, H.Y.; Chen, F.L.; Che, X.Q.; Bi, W.K.; Shi, S.L.; Zhao, J.J. Berberine improves intralipid-induced insulin resistance in murine. Acta Pharmacol. Sin. 2021, 42, 735-743. [CrossRef]

40. Shen, N.; Huan, Y.; Shen, Z.F. Berberine inhibits mouse insulin gene promoter through activation of AMP activated protein kinase and may exert beneficial effect on pancreatic $\beta$-cell. Eur. J. Pharmacol. 2012, 694, 120-126. [CrossRef]

41. Liu, C.; Wang, Z.; Song, Y.; Wu, D.; Zheng, X.; Li, P.; Li, L. Effects of berberine on amelioration of hyperglycemia and oxidative stress in high glucose and high fat diet-induced diabetic hamsters in vivo. Biomed Res. Int. 2015, 2015, 313808. [CrossRef]

42. Collard, B.L.; Boettcher, P.J.; Dekkers, J.C.; Petitclerc, D.; Schaeffer, L.R. Relationships between energy balance and health traits of dairy cattle in early lactation. J. Dairy Sci. 2000, 83, 2683-2690. [CrossRef]

43. De Vries, M.J.; Veerkamp, R.F. Energy balance of dairy cattle in relation to milk production variables and fertility. J. Dairy Sci. 2000, 83, 62-69. [CrossRef]

44. Hsu, Y.Y.; Chen, C.S.; Wu, S.N.; Jong, Y.J.; Lo, Y.C. Berberine activates Nrf2 nuclear translocation and protects against oxidative damage via a phosphatidylinositol 3-kinase/Akt-dependent mechanism in NSC34 motor neuron-like cells. Eur. J. Pharm. Sci. 2012, 46, 415-425. [CrossRef]

45. Bae, J.; Lee, D.; Kim, Y.K.; Gil, M.; Lee, J.Y.; Lee, K.J. Berberine protects 6-hydroxydopamine-induced human dopaminergic neuronal cell death through the induction of heme oxygenase-1. Mol. Cells 2013, 35, 151-157. [CrossRef]

46. Zamuner, F.; Cameron, A.W.N.; Leury, B.J.; DiGiacomo, K. Comparison of measures of insulin sensitivity in early-lactation dairy goats. JDS Commun. 2021, 300-304. [CrossRef]

47. Van Knegsel, A.T.; van der Drift, S.G.; Čermáková, J.; Kemp, B. Effects of shortening the dry period of dairy cows on milk production, energy balance, health, and fertility: A systematic review. Vet. J. 2013, 198, 707-713. [CrossRef] [PubMed]

48. Farney, J.K.; Mamedova, L.K.; Coetzee, J.F.; KuKanich, B.; Sordillo, L.M.; Stoakes, S.K.; Bradford, B.J. Anti-inflammatory salicylate treatment alters the metabolic adaptations to lactation in dairy cattle. Am. J. Physiol. Regul. 2013, 305, 110-117. [CrossRef] [PubMed]

49. Tsiplakou, E.; Mitsiopoulou, C.; Mavrommatis, A.; Karaiskou, C.; Chronopoulou, E.G.; Mavridis, G.; Zervas, G. Effect of underand overfeeding on sheep and goat milk and plasma enzymes activities related to oxidation. J. Anim. Physiol. Anim. Nutr. 2018, 102, e288-e298. [CrossRef]

50. Puppel, K.; Nałęcz-Tarwacka, T.; Kuczyńska, B.; Gołębiewski, M.; Kordyasz, M. Effect of different fat supplements on the antioxidant capacity of cow's milk. Arch. Anim. Breed. 2013, 56, 178-190. [CrossRef]

51. Albera, E.; Kankofer, M. Antioxidants in colostrum and milk of sows and cows. Reprod. Domest. Anim. 2009, 44, 606-611. [CrossRef]

52. Sayiner, S.; Darbaz, I.; Ergene, O.; Aslan, S. Changes in antioxidant enzyme activities and metabolic parameters in dairy cows during different reproductive periods. Theriogenology 2021, 159, 116-122. [CrossRef]

53. Malekinezhad, P.; Ellestad, L.E.; Afzali, N.; Farhangfar, S.H.; Omidi, A.; Mohammadi, A. Evaluation of berberine efficacy in reducing the effects of aflatoxin B1 and ochratoxin A added to male broiler rations. Poult. Sci. 2021, 100, 797-809. [CrossRef]

54. Ghavipanje, N.; Fathi Nasri, M.H.; Farhangfar, H.; Modaresi, J. In situ, in vitro and in vivo nutritive value assessment of Barberry leaf as a roughage for goat feeding. Small Rumin. Res. 2016, 141, 94-98. [CrossRef]

55. Thirupurasundari, C.J.; Padmini, R.; Devaraj, S.N. Effect of berberine on the antioxidant status, ultrastructural modifications and protein bound carbohydrates in azoxymethane-induced colon cancer in rats. Chem.-Biol. Interact. 2009, 177, 190-195. [CrossRef]

56. Bionaz, M.; Vargas-Bello-Pérez, E.; Busato, S. Advances in fatty acids nutrition in dairy cows: From gut to cells and effects on performance. J. Anim. Sci. Biotechnol. 2020, 11, 110. [CrossRef] [PubMed]

57. Eknæs, M.; Kolstad, K.; Volden, H.; Hove, K. Changes in body reserves and milk quality throughout lactation in dairy goats Small Rumin. Res. 2006, 63, 1-11. [CrossRef] 